\section{Abundance of Citrus Leafminer Larvae on Citrus and Citrus-related Germplasm}

\author{
Matthew L. Richardson ${ }^{1}$, Catherine J. Westbrook ${ }^{1}$, David G. Hall ${ }^{2}$, \\ Ed Stover, and Yong Ping Duan \\ U.S. Horticultural Research Laboratory, U.S. Department of Agriculture, \\ Agricultural Research Service, 2001 South Rock Road, Fort Pierce, FL \\ 34945
}

Richard F. Lee

National Clonal Germplasm Repository for Citrus and Dates, U.S. Department of Agriculture, Agricultural Research Service, 1060 Martin Luther King Boulevard, Riverside, CA 92521

Additional index words. Phyllocnistis citrella, resistance, Aurantioideae, Toddalioideae, Rutaceae, Xanthomonas citri subsp. citri

Abstract. The citrus leafminer, Phyllocnistis citrella Stainton (Lepidoptera: Gracillariidae), is a key pest in most citrus-growing regions worldwide. Adult citrus leafminers oviposit primarily on young elongating flush of Citrus as well as other Rutaceae and some ornamental plants. Larvae feed on the epidermal cell layer of developing leaves and injury to leaves provides a pathway for infection by the bacterium Xanthomonas citri subsp. citri (Hasse), the causal agent of Asiatic citrus canker. In this study, we quantified abundance of citrus leafminer larvae on progeny of 87 seed parent genotypes of Citrus and Citrus relatives (family Rutaceae) in the field in East-central Florida to identify those that have low abundance of leafminers. Progeny from the 87 parent genotypes varied in abundance of the leafminer. Progeny of 15 parent genotypes had a high mean abundance of more than six leafminers per flush shoot. All but one of these genotypes were in the Citrus genus. Progeny of 16 parent genotypes had zero, or nearly zero, leafminers, but none were from the Citrus genus. However, many of these $\mathbf{1 6}$ genotypes were from genera closely related to true citrus (subtribe Citrinae) and are sexually compatible with Citrus. Progeny of two parent genotypes in the subfamily Toddalioideae and Glycosmis pentaphylla (Retz.) Corr. also had a low abundance of leafminer. Glycosmis pentaphylla also is a poor host for the Asian citrus psyllid, Diaphorina citri Kuwayama, and has biochemical resistance to the citrus weevil, Diaprepes abbreviatus (L.), so this genotype as well as others identified as poor hosts for the leafminer may prove useful in breeding programs aimed at reducing the abundance of multiple insect pests on citrus.

The citrus leafminer, Phyllocnistis citrella, is native to Southeast Asia but has become a key pest in most citrus-growing regions worldwide (Heppner, 1993). The citrus leafminer was first discovered in major citrus-producing states in the United States (i.e., California, Florida, and Texas) in the 1990s and early 2000s and has rapidly spread throughout these states and

Received for publication 16 May 2011. Accepted for publication 1 July 2011.

Financial support was provided by the Florida Citrus Research and Development Foundation. This article reports the results of research only.

We thank Montserrat Watson, Scott Ciliento, and Jonathan Worton for assistance in the field.

Mention of a trademark or proprietary product is solely for the purpose of providing specific information and does not constitute a guarantee or warranty of the product by the U.S. Department of Agriculture and does not imply its approval to the exclusion of other products that may also be suitable.

${ }^{1}$ These authors contributed equally to the manuscript. ${ }^{2}$ To whom reprint requests should be addressed; e-mail David.Hall@ars.usda.gov. foliar insecticides is often ineffective because larvae are protected from residues within their mines and also may develop resistance to a broad range of insecticides (Villanueva-Jiménez and Hoy, 1998). Biweekly applications of insecticides may be needed to protect emerging, highly susceptible leaf flush, but these insecticides reduce the populations of natural enemies of the leafminer (Smith and Peña, 2002). Classical biological control agents are sometimes effective at reducing populations of citrus leafminer; however, their effectiveness is tempered by environmental conditions (Yoder and Hoy, 1998). The population of natural enemies also lags behind the pest population and, therefore, may provide minimal control early in the growing season (Hoy et al., 2007). Development of effective alternatives to insecticides and classical biological control for management of the citrus leafminer is of critical importance. Host plant resistance ultimately may provide the most effective, economical, environmentally safe, and sustainable method of control, especially if the plant also is resistant to other important pests of citrus.

Traits that confer resistance to insects have been documented among members of the orange subfamily Aurantioideae (Bowman et al., 2001; Luthria et al., 1989; Yang and Tang, 1988). Very little is known about antixenosis or antibiosis of Citrus and relatives to the leafminer. Only two relatives, Bergera koenigii L. and Glycosmis pentaphylla, are known to be completely resistant to the leafminer (Fletcher, 1920; Jacas et al., 1997), but genotypes of Citrus and relatives may differ in susceptibility (Batra and Sandhu, 1983; Heppner, 1993; Jacas et al., 1997; Wilson, 1991), and in some cases, the mechanism conferring avoidance or resistance has been identified (Batra and Sandhu, 1983; Batra et al., 1984; Bernet et al., 2005; Jacas et al., 1997; Padmanaban, 1994; Singh et al., 1988). In this study we quantified abundance of citrus leafminer larvae on progeny of seed parent genotypes of Citrus and Citrus relatives (family Rutaceae) in the field in East-central Florida to identify those that have low abundance of leafminers. Ultimately, Citrus and relatives that have low abundance of the leafminer may have mechanisms that lower the population and economic impact of this pest.

\section{Materials and Methods}

We obtained seeds from 124 accessions of Citrus and relatives in the family Rutaceae (subfamily Aurantioideae) from the USDAARS National Clonal Germplasm Repository for Citrus and Dates located at the University of California at Riverside (UCR). The seeds were collected from the Citrus Variety Collection of UCR (see <http://www.citrusvariety. ucr.edu $>$ ), which was created nearly 100 years ago and contains more than 1100 accessions [each with a unique Citrus Research Center (CRC) number]. Among the seeds from the 124 accessions from the Citrus Variety Collection was the Core Collection of Citrus hybrids, which represents $\approx 85 \%$ of the genetic 


\begin{tabular}{|c|c|c|c|c|}
\hline Botanical name of seed parent ${ }^{y}\left(\mathrm{CRC}^{\mathrm{x}}\right)$ & Common name of seed parent ${ }^{y}$ & No. & Mean rank ${ }^{\mathrm{w}}$ & $\begin{array}{c}\text { Mean } \\
\text { abundance }(0-3)\end{array}$ \\
\hline C. neo-aurantium (C. obovoidea + C. unshiu graft chimera) $(3816)^{\mathrm{u}}$ & Kinkoji unshiu graft chimera & 28 & $456.9^{\mathrm{ab}}$ & 2.8 \\
\hline C. aurantium L. (2717) ${ }^{\mathrm{u}}$ & Olivelands sour orange & 26 & $454.5^{\mathrm{abc}}$ & 2.8 \\
\hline C. excelsa Wester (2317) ${ }^{\mathrm{u}}$ & Limon real (papeda) & 29 & $439.9^{\text {abcd }}$ & 2.7 \\
\hline C. hassaku, hort ex Tan. $(3942)^{\mathrm{u}}$ & Hassaku pummelo hybrid & 30 & $439.6^{\mathrm{abcd}}$ & 2.7 \\
\hline C. nobilis Lour. $(3845)^{\mathrm{u}}$ & King tangor & 26 & $416.7^{\text {abcdefg }}$ & 2.6 \\
\hline C. maxima (Burm.) Merr. (4026) ${ }^{\mathrm{u}}$ & Pomelit pummelo hybrid & 29 & $410.5^{\text {abcdefgh }}$ & 2.5 \\
\hline$\times$ Citroncirus sp. $($ C. paradisi 'Duncan’ $\times P$. trifoliata $)(3771)$ & Swingle citrumelo & 32 & $408.2^{\text {abcdefgh }}$ & 2.5 \\
\hline C. aurantium L. (3929) & Gou tou cheng & 31 & $407.6^{\text {abcdefgh }}$ & 2.5 \\
\hline C. medica L. (661) & Indian citron hybrid & 26 & $406.8^{\text {abcdefgh }}$ & 2.5 \\
\hline C. maxima (Burm.) Merr. (2242) & Kao pan pummelo & 28 & $403.7^{\text {abcdefgh }}$ & 2.4 \\
\hline C. macrophylla Wester $(3842)^{\mathrm{u}}$ & Alemow & 30 & $392.5^{\text {bcdefghijk }}$ & 2.4 \\
\hline C. volkameriana/C. limonia Osbeck (3050) & Volkamer lemon hybrid & 26 & $391.8^{\text {bcdefghijkl }}$ & 2.4 \\
\hline C. davaoensis (Wester) Tan. (2427) & Davao lemon (papeda) & 27 & $391.2^{\text {bcdefghijkl }}$ & 2.3 \\
\hline C. limon L. Burm. $f .(3005)^{\mathrm{u}}$ & Frost nucellar eureka lemon & 26 & $388.5^{\text {cdefghijklm }}$ & 2.3 \\
\hline C. limon (L.) Burm. f. $(3892)^{\mathrm{u}}$ & Mesero lemon & 28 & $385.8^{\text {defghijklm }}$ & 2.3 \\
\hline C. reticulata Blanco $(3022)^{\mathrm{u}}$ & Frua mandarin & 28 & $385.6^{\text {defghijklm }}$ & 2.3 \\
\hline C. neo-aurantium Tan. $(3611)^{\mathrm{u}}$ & Konejime sour orange hybrid & 26 & $384.7^{\text {defghijklmn }}$ & 2.3 \\
\hline C. reticulata Blanco $(2590)^{\mathrm{u}}$ & Tien chieh mandarin & 27 & $382.4^{\text {defghijklmno }}$ & 2.4 \\
\hline C. limonia (L.) Osbeck (712) & Santa barbara red lime & 31 & $382.1^{\text {defghijklmno }}$ & 2.3 \\
\hline C. jambhiri Lush. (400) & Florida rough lemon & 30 & $379.8^{\text {defghijklmno }}$ & 2.3 \\
\hline C. aurantium L. (3930) & Zhuluan sour orange hybrid & 23 & $378.6^{\text {defghijklmnop }}$ & 2.3 \\
\hline C. reticulata hybrid (Clementine $\times$ Orlando) $(3851)^{\mathrm{u}}$ & Lee mandarin & 23 & $369.4^{\text {efghijklmnopq }}$ & 2.3 \\
\hline C. reticulata hybrid (Clementine $\times$ Orlando) $(3850)^{\mathrm{u}}$ & Robinson mandarin & 31 & $366.7^{\text {fghijklmnopq }}$ & 2.2 \\
\hline C. reticulata Blanco $(3812)^{\mathrm{u}}$ & Unnamed mandarin & 28 & $366.4^{\text {fghijklmnopq }}$ & 2.1 \\
\hline C. medica L. $(3546)^{\mathrm{u}}$ & South coast field station citron & 29 & $345.6^{\text {hijklmnopqr }}$ & 2.0 \\
\hline C. intermedia hort. ex Tan. (3474) & Yama-mikan sour orange & 27 & $345.1^{\text {hijklmnopqrs }}$ & 2.1 \\
\hline C. aurantiifolia (Christm.) Swing. $(2450)^{\mathrm{u}}$ & India lime & 29 & $336.4^{\mathrm{ijklmn} n o p q r s t}$ & 2.0 \\
\hline C. limon (L.) Burm. f. (3176) ${ }^{\mathrm{u}}$ & Frost nucellar Lisbon lemon & 27 & $334.3^{\text {jklmnopqrst }}$ & 2.0 \\
\hline C. longispina Wester $(2320)^{\mathrm{u}}$ & Talamisan & 28 & $332.5^{\text {jklmnopqrst }}$ & 2.0 \\
\hline$\times$ Citroncirus sp. $(3552)$ & S-281 citrangelo & 29 & $331.7^{\mathrm{klmnopqrst}}$ & 1.9 \\
\hline C. reticulata Blanco (4003) & Sun chu sha mandarin & 28 & $329.8^{\mathrm{klmnopqrst}}$ & 1.9 \\
\hline C. medica L. (3523) & Diamante citron & 31 & $328.1^{\text {lmnopqrst }}$ & 1.9 \\
\hline C. hybrid (53-1-16 'Clem' $\times$ 'Hamlin') $\times$ Chinotto F1 (3715) & Sour orange hybrid ex-india & 25 & $323.1^{1 \mathrm{mnopqrst}}$ & 2.0 \\
\hline C. sinensis (L.) Osbeck (3858) & Pineapple sweet orange & 29 & $322.6^{\mathrm{mnopqrst}}$ & 1.9 \\
\hline C. reticulata (3326) & Scarlet emperor mandarin & 27 & $317.6^{\text {nopqrst }}$ & 1.9 \\
\hline C. aurantium L. (628) & Standard sour orange & 28 & $316.2^{\text {opqrst }}$ & 1.9 \\
\hline C. aurantiifolia (Christm.) Swing. $(3822)^{\mathrm{u}}$ & Mexican lime type & 29 & $313.1^{\text {pqrst }}$ & 1.8 \\
\hline C. amblycarpa Och. $(2485)^{\mathrm{u}}$ & Nasnaran mandarin & 29 & $309.7^{\text {qrst }}$ & 1.8 \\
\hline C. maxima (Burm.) Merr. (3945) & Mato buntan pummelo & 22 & $299.7^{\text {qrstu }}$ & 1.7 \\
\hline ×Citroncirus sp. (301) & Rusk citrange trifoliate hybrid & 30 & $288.4^{\text {rstu }}$ & 1.6 \\
\hline C. lycopersiciformis hort. ex Tan. (3564) & Monkey orange & 28 & $288.4^{\text {rstu }}$ & 1.6 \\
\hline C. latipes (Swing.) Tan. (3052) & Khasi papeda & 27 & $279.5^{\text {stu }}$ & 1.6 \\
\hline Severinia buxifolia (Poiret) Tan. (1497) & Chinese box orange & 25 & $272.9^{\text {tu }}$ & 1.5 \\
\hline C. reticulata Blanco $(3363)^{\mathrm{u}}$ & Belady mandarin & 27 & $265.4^{\text {tu }}$ & 1.5 \\
\hline C. webberi Wester $(1455)^{\mathrm{u}}$ & Kalpi papeda & 30 & $263.2^{\text {tuv }}$ & 1.4 \\
\hline C. leiocarpa hort. ex Tan. (3147) & Koji mandarin & 26 & $253.9^{\text {tuvw }}$ & 1.5 \\
\hline C. aurantium L. (3289) ${ }^{\mathrm{u}}$ & Sour orange var. salicifolia & 10 & $246.1^{\text {turwx }}$ & 1.3 \\
\hline Poncirus trifoliata L. (4007) & "Little-leaf" trifoliate & 31 & $232.9^{\text {uvwx }}$ & 1.2 \\
\hline$\times$ Citroncirus sp. $($ Cleopatra mandarin $\times$ trifoliate) $(3957)$ & X639 trifoliate hybrid & 31 & $200.6^{\mathrm{vwxy}}$ & 1.0 \\
\hline C. halimii B.C. Stone $(3780)^{\mathrm{u}}$ & Unnamed & 26 & $192.6^{\mathrm{wxyz}}$ & 1.0 \\
\hline Afraegle paniculata (Schum.) Engl. & Nigerian powder flask fruit & 31 & $190.2^{\text {wxyz }}$ & 0.9 \\
\hline
\end{tabular}




\begin{tabular}{|c|c|c|c|c|}
\hline Botanical name of seed parent ${ }^{\mathrm{y}}\left(\mathrm{CRC}^{\mathrm{x}}\right)$ & Common name of seed parent ${ }^{y}$ & No. & Mean rank ${ }^{\mathrm{w}}$ & $\begin{array}{c}\text { Mean } \\
\text { abundance }(0-3)^{\mathrm{v}}\end{array}$ \\
\hline 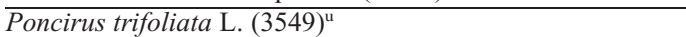 & Simmons trifoliate & 28 & $136.7^{\mathrm{yzAB}}$ & 0.5 \\
\hline$\times$ Microcitronella $\mathrm{sp} .($ M. australasica $\times$ Calamondin $)(1466)$ & Faustrimedin & 26 & $133.1^{\mathrm{zAB}}$ & 0.5 \\
\hline Balsamocitrus dawei Stapf (3514) & Uganda powder-flask & 38 & $132.0^{\mathrm{zAB}}$ & 0.4 \\
\hline Microcitrus australis (Planch.) Swing. (3673) & Australian round lime & 26 & $120.3^{\mathrm{AB}}$ & 0.4 \\
\hline Eremocitrus glauca (Lindley) Swing. Hybrid (4105) & Australian desert lime hybrid & 30 & $118.5^{\mathrm{AB}}$ & 0.3 \\
\hline Aegle marmelos (L.) Corr. & Indian bael fruit & 27 & $95.0^{\mathrm{B}}$ & 0.1 \\
\hline Glycosmis pentaphylla (Retz.) Corr. (3285) & Orangeberry/gin berry & 32 & $94.7^{\mathrm{B}}$ & 0.1 \\
\hline Bergera koenigii L. (3165) & Curry tree & 31 & $92.6^{\mathrm{B}}$ & 0.1 \\
\hline Microcitrus australasica (F.J. Muell.) Swing. (1484) & Australian finger lime 'Sanguinea' & 22 & $86.8^{\mathrm{B}}$ & 0.0 \\
\hline Casimiroa edulis Llave et Lex (-) & White sapote & 32 & $85.7^{\mathrm{B}}$ & 0.0 \\
\hline Murraya paniculata L. (3171) & var. ovatifoliolata & 31 & $83.8^{\mathrm{B}}$ & 0.0 \\
\hline Murraya paniculata (L.) Jack (1637) & Orange Jessamine & 29 & $82.9^{\mathrm{B}}$ & 0.0 \\
\hline Clausena excavata Burm. f. (3166) & Pink wampee & 32 & $81.1^{\mathrm{B}}$ & 0.0 \\
\hline Zanthoxylum ailanthoides L. (-) & Japanese prickly-ash & 31 & $79.7^{\mathrm{B}}$ & 0.0 \\
\hline Clausena harmandiana (Pierre) Guillaumin (4034) & Unnamed & 27 & $78.4^{\mathrm{B}}$ & 0.0 \\
\hline
\end{tabular}

Japanese prickly-ash

${ }^{\mathrm{z}}$ Members of the Rutaceae vary greatly in their incidence of nucellar embryony, so some of the plants tested were essentially genetically identical to the seed parent, whereas others were sexual hybrids.

yBotanical and common names specified by Citrus Variety Collection, Riverside, CA (http://www.citrusvariety.ucr.edu).

xAccession number assigned by Citrus Research Center and maintained by the Citrus Variety Collection.

${ }^{\text {w}}$ Mean rank was calculated using a nonparametric Friedman's test and ranks with different letters (or capitalization) are significantly different.

${ }^{v}$ Abundance of larvae was quantified on a 0 to 3 ordinal scale: $0=$ no larvae; $1=$ one to two larvae; $2=$ three to six larvae; and three to six or more larvae.

"From the Core Collection of Citrus hybrids, which represents $\approx 85 \%$ of the genetic diversity at the Citrus Variety Collection.

diversity of the UCR collection (Barkley, 2003). We also obtained seed from the subfamily Aurantioideae, Afraegle paniculata (Schum.) Engl. and Aegle marmelos (L.) Corr., and the subfamily Toddalioideae, Casimiroa edulis (Llave et Lex) and Zanthoxylum ailanthoides (L.), from the Fruit and Spice Park (Miami/Dade County, FL) and the University of Georgia. Members of the Rutaceae vary greatly in their incidence of nucellar embryony (reviewed in Frost and Soost, 1968); therefore, some of the plants we tested were genetically identical to the female parent, whereas others were sexual hybrids. Phylogenetic relationships of the seed parent genotypes (hereafter "parent genotypes") we used are described in Barkley (2003) and Bayer et al. (2009).

We planted seeds of each parent genotype in individual plastic cells $(3.8 \times 21 \mathrm{~cm})(\mathrm{SC}-10$ super cell Cone-tainers; Stuewe and Sons, Corvallis, OR) containing sterile potting mix. Seedlings of 87 parent genotypes were successfully propagated in a greenhouse at the USDA-ARS U.S. Horticultural Research Laboratory in Fort Pierce, FL. We transplanted seedlings to 3.7-L containers 4 to 7 months after sowing and grew them in a greenhouse with a mean diurnal temperature cycle of $35^{\circ} \mathrm{C}$ maximum and $23^{\circ} \mathrm{C}$ minimum in the summer and 32 and $20^{\circ} \mathrm{C}$ in the winter. We watered plants daily and fertilized them weekly.

After growing plants for 6 to 9 months in the greenhouse, we planted one seedling of each parent genotype in each of eight randomized complete blocks on a research farm owned by the USDA-ARS (Fort Pierce, FL) during June and July 2009. An additional plant derived from Balsamocitrus dawei Staph (CRC 3514) was planted in each of two blocks. Trees were planted in three rows with $0.6-\mathrm{m}$ spacing between trees in a row and $3.5 \mathrm{~m}$ between rows. We regularly irrigated and fertilized trees using a program similar to that used for new commercial plantings of citrus. No pesticides were applied during the study. We surveyed the trees four times, at approximately monthly intervals from June to Sept. 2010, to measure the abundance of citrus leafminer larvae.

We estimated abundance of leafminers only on trees with a minimum of one flush shoot because larvae are dependent on flush to feed and develop. A tree was omitted during a survey time if no flush was present. Flush was defined as any shoot with developing leaves, which included newly breaking buds to shoots with expanded but tender young leaves (Hall and Albrigo, 2007). Morphology of plants and flush differed, which necessitated careful examination of each plant to locate flush. We sampled progeny from all parent genotypes on each date, but obtained the maximum number of samples (32 or 40 across all dates) for only five genotypes (Table 1). The mean number of samples per parent genotype was 28 as a result of the lack of synchronous flushing by plants on our sampling dates. For plants with multiple flush shoots, the first shoot found to contain leafminers was used to determine abundance for that replicate. Abundance of larvae was estimated visually and quantified on a 0 to 3 ordinal scale: $0=$ no larvae; $1=$ one to two larvae; $2=$ three to six larvae; and $3=$ more than six larvae. Whereas integer counts likely would identify smaller effects of genotype on abundance of leafminer, categorical counts were adequate to meet our objective and necessary to sample all replicates in a reasonable time period. Our counts do not directly consider the severity of the mines. Most of the mines appeared well developed, and the number of days mining as well as the number of larvae per leaf is correlated with damage (Schaffer et al., 1996), so our counts are likely correlated with severity of the mines.

Statistical analyses. We tested whether the abundance of citrus leafminer differed among seedlings of the 87 parent genotypes using a non-parametric repeated-measures analysis: the F-approximation of the Friedman test (Ipe, 1987) and the associated rank sum multiple comparison test (PROC GLM; SAS Institute, 2008).

\section{Results and Discussion}

Abundance of citrus leafminer larvae varied among progeny of the 87 parent genotypes of citrus and citrus relatives $(\mathrm{F}=22.9, \mathrm{df}=$ $86, P<0.001$; Table 1). Progeny of 15 parent genotypes averaged nearly 3 on our ordinal scale, meaning they had more than six larvae per flush shoot (Table 1). All of these genotypes, except for $\times$ Citroncirus sp. (CRC 3771), were in the genus Citrus. Progeny of many parent genotypes in the genus Citrus had a moderate to low abundance of leafminer. However, wounds caused by the leafminer are susceptible to infection by the canker bacterium for a relatively long period of time and require only a small concentration of inoculum (Christiano et al., 2007), so even a low abundance of leafminer may increase the rate of infection of a tree.

Progeny of 16 parent genotypes had zero, or nearly zero, leafminers, and none of these were in the genus Citrus (Table 1). However, this group includes genotypes from other genera of true citrus (subtribe Citrinae) that are sexually compatible with Citrus (Swingle, 1943; Swingle and Reece, 1967): Microcitrus hybrid (CRC 1485); Poncirus trifoliata 'Simmons trifoliate' (CRC 3549); $\times$ Microcitronella sp. (CRC 1466); M. australis (3673); Eremocitrus glauca (CRC 4105); and M. australasica (CRC 1484). Poncirus trifoliata is the only species in this group previously identified as having some resistance to the leafminer, but we used a different cultivar than the previous study (Bernet et al., 2005). There are four major groups of Poncirus (Fang et al., 1997) and our limited data on this genus suggest that abundance of leafminer larvae may vary 
among large-flowered and small-flowered genotypes (Table 1). P. trifoliata is graftcompatible with Citrus, is used as rootstock in many citrus-growing regions (Krueger and Navarro, 2007; Ziegler and Wolfe, 1981), and is an important parent in intergeneric hybrids with Citrus (Krueger and Navarro, 2007). Therefore, P. trifoliata may be useful in breeding programs as a potential source of genes that confer resistance to insects.

Progeny from additional parent genotypes had a low or zero abundance of leafminer, including those in the subfamily Toddalioideae, Casimiroa edulis and Z. ailanthoides, and two genotypes previously identified as resistant to the leafminer, B. koenigii and G. pentaphylla (Fletcher, 1920; Jacas et al., 1997). Glycosmis pentaphylla is a remote citroid fruit (Swingle, 1943; Swingle and Reece, 1967) and is sexually incompatible with species in the genus Citrus. However, genes identified in G. pentaphylla that prove to confer resistance to insects could be transferred to cultivated varieties of citrus using transgenic or intragenic methods (Rommens et al., 2007). Glycosmis pentaphylla also is an unfavorable host to the Asian citrus psyllid and has biochemical resistance against the citrus weevil, Diaprepes abbreviatus (L.) (Shapiro et al., 1997, 2000). We did not test the influence that colonization by other insect species such as the Asian citrus psyllid had on abundance of citrus leafminer. The Asian citrus psyllid concurrently infested many of these trees and probably colonizes new flush earlier than the citrus leafminer. However, competition between the insect species was not apparent because the patterns of abundance of the two species were similar across progeny of the parent genotypes (Westbrook et al., 2011). For example, in addition to $G$. pentaphylla, the following genotypes had low abundances of both insect species: Aegle marmelos, C. edulis, Clausena harmandiana, E. glauca, M. australasica, a Microcitrus hybrid (CRC 1485), P. trifoliata 'Simmons trifoliate', and Z. ailanthoides (Westbrook et al., 2011). Therefore, these genotypes may be useful in breeding programs aimed at reducing populations of multiple insect pests.

In conclusion, the majority of the progeny we evaluated supported a moderate to high abundance of citrus leafminer, confirming the broad range of hosts for this insect pest within the Aurantoideae (Heppner, 1993; Jacas et al., 1997; Pandey and Pandey, 1964). However, some true citrus and citrus relatives had virtually no larval leafminers, which indicates that they may lack cues that attract the leafminer, may not be preferred in a choice situation, or may possess mechanisms that confer resistance to the leafminer. Resistance may result from morphological or chemical defenses that deter leafminers or reduce their fitness. In our study we used young trees in a polyculture and attractiveness or resistance in some plant species to insects may vary as a result of the age of the plant or attributes of neighboring plants (Smith, 2005). Identifying whether resistance is expressed by these genotypes throughout the lifespan of the tree and in monoculture and identifying genes that confer resistance are the next steps toward developing citrus varieties that limit leafminer populations and, indirectly, the spread of Asiatic citrus canker.

\section{Literature Cited}

Barkley, N.L.A. 2003. Genetic diversity in a citrus germplasm collection characterized with simple sequence repeat markers. PhD diss., Univ. Calif., Riverside, CA.

Batra, R.C., K.L. Baja, and G.S. Sandhu. 1984. Phenolic content in relation to incidence of citrus leafminer in citrus germplasm. J. Res. Punjab Agr. Univ. 21:203-206.

Batra, R.C. and G.S. Sandhu. 1983. Screening of citrus germplasm for citrus leafminer in the Punjab. J. Res. Punjab Agr. Univ. 18:221-223.

Bayer, R.J., D.J. Mabberley, C. Morton, C.H. Miller, I.K. Sharma, P. Pfeil, S. Rich, R. Hitchcock, and S. Sykes. 2009. A molecular phylogeny of the orange subfamily (Rutaceae: Aurantioideae) using nine cpDNA sequences. Amer. J. Bot. 96:668-685.

Belasque, J., A. Parra-Pedrazzoli, J. Rodrigues, P. Yammamoto, M. Chagas, J. Parra, and J.S. Hartung. 2005. Adult citrus leafminer (Phyllocnistis citrella) are not vectors for citrus canker in experimental microcosms. Plant Dis. 89:590-594.

Bernet, G.P., C. Margaix, J. Jacas, E.A. Carbonell, and M.J. Asins. 2005. Genetic analysis of citrus leafminer susceptibility. Theor. Appl. Genet. 110:1393-1400.

Bowman, K.D., J.P. Shapiro, and S.L. Lapointe. 2001. Sources of resistance to Diaprepes weevil in subfamily Aurantioideae, Rutaceae. HortScience 36:332-336.

Chagas, M.C.M., J.R.P. Parra, T. Namekata, J.S. Hartung, and P.T. Yamamoto. 2001. Phyllocnistis citrella Stainton (Lepidoptera: Gracillariidae) and its relationship with the citrus canker bacterium Xanthomonas axonopodis pv citri in Brazil. Neotrop. Entomol. 30:55-59.

Christiano, R.S.C., M.D. Pria, W.C. Jesus Jr, J.R.P. Parra, L. Amorim, and A. Bergamin Filho. 2007. Effect of citrus leaf-miner damage, mechanical damage, and inoculum concentration on severity of symptoms of Asiatic citrus canker in Tahiti lime. Crop Prot. 26:59-65.

Fang, D.Q., M.L. Roose, R.R. Krueger, and C.T Federici. 1997. Fingerprinting trifoliate orange germplasm accessions with isozymes, RFLPs, and inter-simple sequence repeat markers. Theor. Appl. Genet. 95:211-219.

Fletcher, T.B. 1920. Life histories of Indian insects. Microlepidoptera Mem. Dep. Agr. India 6:1-217.

Frost, H.B. and R.K. Soost. 1968. Seed reproduction: Development of gametes and embryos, $\mathrm{p}$. 290-324. In: Reuther, W., L.D. Batchelor, and H.J. Webber (eds.). The citrus industry. Vol. 2. Anatomy, physiology, genetics, and reproduction. Univ. California, Berkeley, CA.

Hall, D.G. and L.G. Albrigo. 2007. Estimating the relative abundance of flush shoots in citrus, with implications on monitoring insects associated with flush. HortScience 42:364-368.

Hall, D.G., T.R. Gottwald, and C.H. Bock. 2010. Exacerbation of citrus canker by citrus leafminer Phyllocnistis citrella in Florida. Fla. Entomol. 93:558.

Heppner, J.B. 1993. Citrus leafminer (CLM), Phyllocnistis citrella Stainton in Florida (Lepidoptera: Gracillariidae: Phyllocnistinae). Trop. Lepid. 4:49-64.

Hoy, M.A. and R. Nguyen. 1997. Classical biological control of the citrus leafminer Phyllocnistis citrella Stainton (Lepidoptera: Gracillariidae): Theory, practice, art, and science. Trop. Lepid. 8(suppl. 1):1-19.

Hoy, M.A., R. Singh, and M.E. Rogers. 2007. Citrus leafminer, Phyllocnistis citrella (Lepidoptera: Gracillariidae), and natural enemy dynamics in central Florida during 2005. Fla. Entomol. 90:358-369.

Ipe, D. 1987. Performing the Friedman test and the associated multiple comparison test using PROC GLM. Proc. 12th Annu. SAS Users Group Int. Conf. SAS Institute, Cary, NC. p. 1146-1148.

Jacas, J.A., A. Garrido, C. Margaix, J. Forner, A. Alcalde, and J.A. Pina. 1997. Screening of different citrus rootstocks and citrus-related species for resistance to Phyllocnistis citrella (Lepidoptera: Gracillariidae). Crop Prot. 16: 701-705.

Krueger, R.R. and L. Navarro. 2007. Citrus germplasm resources, p. 45-140. In: Khan, I.A. (ed.). Citrus genetics, breeding and biotechnology. $\mathrm{CAB}$ International, Wallingford, Oxfordshire, UK.

Legaspi, J.C., J.V. French, M.E. Schauff, and J.B. Woolley. 1999. The citrus leafminer Phyllocnistis citrella (Lepidoptera: Gracillariidae) in south Texas: Incidence and parasitism. Fla. Entomol. 82:305-316.

Luthria, D.L., V. Ramakrishnan, G.S. Verma, B.R. Prabhu, and A. Banerji. 1989. Insect antifeedants from Atalantia racemosa. J. Agr. Food Chem. 37:1435-1437.

Padmanaban, B. 1994. Screening of citrus germplasm for controlling citrus leaf-miner (Phyllocnistis citrella) (Lepidoptera: Phyllocnistidae). Indian J. Agr. Sci. 64:723-726.

Pandey, N.D. and Y.D. Pandey. 1964. Bionomics of Phyllocnistis citrella St. (Lepidoptera: Gracillariidae). Indian J. Entomol. 26:417-423.

Peña, J.E., A. Hunsberger, and B. Schaffer. 2000. Citrus leafminer (Lepidoptera: Gracillariidae) density: Effect on yield of 'Tahiti' lime. J. Econ. Entomol. 93:374-379.

Pomerinke, M.A. and P.A. Stansly. 1998. Establishment of Ageniaspis citricola (Hymenoptera: Encyrtidae) for biological control of Phyllocnistis citrella (Lepidoptera: Gracillariidae) in Florida. Fla. Entomol. 81:361-372.

Powell, C.A., M.S. Burton, R. Pelosi, M.A. Ritenour, and R.C. Bullock. 2007. Seasonal abundance and insecticidal control of citrus leafminer in a citrus orchard. HortScience 42:1636-1638.

Rommens, C.M., M.A. Haring, K. Swords, H.V. Davies, and W.R. Belknap. 2007. The intragenic approach as a new extension to traditional plant breeding. Trends Plant Sci. 12:397-403.

SAS Institute. 2008. Statistical analysis system, Version 9.2. SAS Institute, Cary, NC.

Schaffer, B., J. Peña, C.A. Colls, and A. Hunsberger. 1996. Accuracy of visual estimates of leaf damage from citrus leafminer and the relationship between density and mining period on leaf damage and photosynthesis of 'Tahiti' lime leaves, p. 97. In: Hoy, M. (ed.). Proc. of international conference on managing citrus leafminer. Univ. Fla., Gainesville, FL.

Sétamou, M., D. Rodriguez, R. Saldana, G. Schwarzlose, D. Palrang, and S.D. Nelson. 2010. Efficacy and uptake of soil-applied imidacloprid in the control of Asian citrus psyllid and a citrus leafminer, two foliar-feeding citrus pests. J. Econ. Entomol. 103:1711-1719.

Shapiro, J.P., K.D. Bowman, and S.L. Lapointe. 2000. Dehydrothalebanin, a source of resistance from Glycosmis pentaphylla against the citrus root weevil Diaprepes abbreviatus. J. Agr. Food Chem. 48:4404-4409. 
Shapiro, J.P., K.D. Bowman, and H. Smith. 1997. Resistance of citrus rootstocks and Glycosmis pentaphylla against larval Diaprepes abbreviatus (Coleoptera: Curculionidae) in live root or dietincorporation assays. Fla. Entomol. 8:471-477.

Singh, S.P., N.S. Rao, K.K. Kumar, and B.S. Bhumannavar. 1988. Field screening of citrus germplasm against the citrus leafminer Phyllocnistis citrella Stainton. Indian J. Entomol. 50:69-75.

Smith, C.M. 2005. Plant resistance to arthropods. Springer, Dordrecht, The Netherlands.

Smith, D. and J.E. Peña. 2002. Tropical citrus pests, p. 57-101. In: Peña, J.E., J.L. Sharp, and M. Wysoki (eds.). Tropical fruit pests and pollinators: Biology, economic importance, natural enemies, and control. $\mathrm{CAB}$ International, Wallingford, Oxfordshire, UK.
Swingle, W.T. 1943. The botany of Citrus and its wild relatives of the orange subfamily, p. 129474. In: Batchelor, L.D. and H.J. Webber (eds.). The citrus industry. 1st Ed., Vol. 1. History, world distribution, botany, and varieties. Univ. California, Berkeley, CA.

Swingle, W.T. and P.C. Reece. 1967. The botany of citrus and its wild relatives of the orange subfamily, p. 190-430. In: Reuther, W., H.J. Webber, and L.D. Batchelor (eds.). The citrus industry. 2nd Ed., Vol. 1. History, world distribution, botany, and varieties. Univ. California, Berkeley, CA.

Villanueva-Jiménez, J.A. and M.A. Hoy. 1998. Constraints on developing an integrated pest management program for citrus leafminer (Lepidoptera: Gracillariidae) in Florida nurseries. HortTechnology 8:332-345.
Westbrook, C.J., D.G. Hall, E.W. Stover, Y.P. Duan, and R.F. Lee. 2011. Susceptibility of Citrus and Citrus-related germplasm to Diaphorina citri (Hemiptera: Psyllidae). HortScience. 46:997-1005.

Wilson, C.G. 1991. Notes on Phyllocnistis citrella Stainton (Lepidoptera: Phyllocnistidae) attacking four citrus varieties in Darwin. J. Aust. Entomol. Soc. 30:77-78.

Yang, R.Z. and C.S. Tang. 1988. Plants used for pest control in China: A literature review. Econ. Bot. 42:376-402.

Yoder, J.A. and M.A. Hoy. 1998. Differences in water relations among the citrus leafminer and two different populations of its parasitoid inhabiting the same apparent microhabitat. Entomol. Exp. Appl. 89:169-173.

Ziegler, L.W. and H.S. Wolfe. 1981. Citrus growing in Florida. 3rd Ed. Univ. Fla. Press, Gainesville, FL. 